\title{
RESPONSE OF SOME MAIZE HYBRIDS TO DIFFERENT NITROGEN FERTILIZATION LEVELS AND FILTER MUD CAKE FOR SUGAR PRODUCTION. \\ IBrahim,M.M. ${ }^{1}$; N.A.E. Azzaz ${ }^{2}$; Y.A.M.Khalifa ${ }^{1}$ and R.M.H. El-Mazny' \\ ${ }^{1}$ Agron Dept, Fac of Agric, Al-Azhar Univ, Assuit, Egypt. \\ ${ }^{2}$ Biochem Dept, Fac of Agric, Damietta Univ, Damietta, Egypt.
}

\begin{abstract}
Two field experiments were conducted at Bardies, Sohag Governorate, Egypt, during the summer seasons of 2011 and 2012. The objective of this investigation aimed to study the response of some maize hybrids to different nitrogen fertilization levels and filter mud cake. A split-split plot design with three replications was used. Two Maize Hybrids $\left(\mathrm{H}_{1}\right.$ - Single cross Watania-4 and $\mathrm{H}_{2}$ - Three way cross$310)$ were allocated in the main plots. Nitrogen fertilization levels $\left(N_{1}-80, N_{2}-100\right.$ and $\mathrm{N}_{3} 120 \mathrm{~kg} \mathrm{~N} / \mathrm{fed}$ ) were distributed in the sub plots. While, organic fertilizer (filter mud cake $\mathrm{B}_{1}$ - Control (without addition, $\mathrm{B}_{2^{-}}$one ton/fed, $\mathrm{B}_{3}-1.5$ ton/fed and $\mathrm{B}_{4}-2$ ton/fed) were randomly distributed in the sub-sub plots.

The results indicated that single cross Watania-4 surpassed significantly three way cross 310 in ear length $\mathrm{cm}$, ear diameter $\mathrm{cm}$, number of rows/ear, number of kernel/ear, ear weight gm, grains weight/ear gm, 100-grain weight gm and grain yield (ardab/feddan). There were gradual and significant increases in ear length $\mathrm{cm}$, ear diameter $\mathrm{cm}$, number of rows/ear, number of kernel/ear, ear weight gm, grains weight/ear gm, 100-grain weight $\mathrm{gm}$ and grain yield (ardab/feddan) resulted from raising mineral $\mathrm{N}$-level from 80 to 100 and $120 \mathrm{~kg} \mathrm{~N} / \mathrm{fed}$.

There were significant differences in the studied traits as affected by the organic fertilizer (filter mud cake) in both seasons. Under Sohag Governorate conditions of the present work, growing single cross Watania-4 fertilized with 120 $\mathrm{N} /$ fed and applied 2.0 ton filter mud cake that were recommended to get the maximum grain yield (ardab/feddan).

Key words: Maize hybrids, ear length, ear diameter, number of rows/ear, ear weight, number of kernel/ear, 100-grain yield and grain yield ardab/fed.
\end{abstract}

\section{INTRODUCTION}

Maize (Zea mays L.) is one of the most important cereal crops grown principally during the summer season in Egypt. Nitrogen is very important nutrient element in maize production than other filed crops, Shafshak et al. (1994) pointed that the increase in mineral $\mathrm{N}$ levels from zero to 45, 90 and $135 \mathrm{~kg} / \mathrm{fed}$ significantly increased ear height, number of ears/plant, ear length, ear diameter, ear weight, 100-grain weight and grain yield/fed. Gouda and El-Banna (1995) stated that number of ears/plant, ear length, 100-grain weight and grain yield/fed were significantly increased by increasing nitrogen fertilizer levels from 60 to $120 \mathrm{~kg} \mathrm{~N} / \mathrm{fed}$. Salem (2000) revealed that applying $120 \mathrm{~kg} \mathrm{~N} / \mathrm{fed}$ gave the highest ear length, ear diameter, number of rows/ear, number of kernels/row, ears weight, grain weight/ear, grain yield per feddan. Abd El-Aty (2007) stated that increasing nitrogen fertilizer levels from 60 to $120 \mathrm{~kg} \mathrm{~N} / \mathrm{fed}$ significantly increased height, ear length, ear diameter, number of rows/ear, number of kernels/row and grain yield/fed., Attia et al. (2008) 
stated that application nitrogen fertilization at the level of $125 \mathrm{~kg} \mathrm{~N} / \mathrm{fed}$ significantly increased plant and ear height, ear length and diameter, number of ears/plant, number of rows/ear, number of grains/row, ear weight, ear grains weight, 100 grain weight and grain yield yield/fed. compared with other levels (75 and $100 \mathrm{~kg} \mathrm{~N} / \mathrm{fed}$ ) in both seasons. Ahmed, Manar (2009) declared that ear length was increased with increasing $\mathrm{N}$ levels from 40 to 80 and 120 $\mathrm{kg} \mathrm{N} / \mathrm{fed}$ whereas, number of rows/ear, number of grains/row, 100-grain weight, grain shelling percentage, grain yield/plant and grain yield/fed were significantly increased by adding $80 \mathrm{~kg} \mathrm{~N} / \mathrm{fed}$. Similar conclusions were reported by Bamuaafa (2012). Maryam Jasemi et al. (2013) reported that nitrogen application significantly affected all studied traits expect number of kernels/ row. Application of $150 \mathrm{~kg} / \mathrm{ha}$ produced grain yield of $11768 \mathrm{~kg} / \mathrm{ha}$ while non using nitrogen fertilizer produced of $6547 \mathrm{~kg} / \mathrm{ha}$. On the other hand, with increasing nitrogen fertilizer from $150 \mathrm{~N} \mathrm{~kg} / \mathrm{ha}$ to $200 \mathrm{~N} \mathrm{~kg} / \mathrm{ha}$ decreased grain yield.

Maize hybrids differed in its productivity as well as its response to nitrogen fertilization. Ahmed and Mekki (2005) confirmed that maize S.C. Bashair-13 surpassed T.W.C.-310 in ear length, 100-grain weight and grain yield/feddan. Ibrahim and Hala, Kandil (2007) study aimed to evaluate the yield characters of maize plant CV. single cross-10 (S. C.10) as well as the grain chemical constituents. The highest values of plant height, ear characters (length, diameter and weight) as well as ears and grains yield of corn plants per feddan. Mansour and Abd El Maksoud (2009) pointed out that T.W.C. 310 maize hybrid was superior in each of number of rows/ear, number of grains/row, number of grains/ear. 100-grain weight compared with S.C.-122. Ahmed, Howida (2011) demonstrated that maize hybrids S.C. Watania-4 significantly surpassed T.W.C.-310 for ear height, ear diameter, number of rows/ear, number of grains/row, 200-grain weight, grain yield/fed. Moharram, Zainab (2011) found that four hybrids of maize namely white single cross S.C. Watania, yellow single cross Shams, white three Way Cross-310 and yellow three Way Cross-351 possessed a marked differences in growth characters, yield components and grains quality. Single cross hybrids were superior in ear height, ear diameter, number of rows/ear, number of grains/row, 100-grain weight, grain yield/fed as compared with three-way cross hybrids. Bamuaafa (2012) found that single cross hybrid Watania-4 was superior in plant height, ear height, ear leaf area, ear length, ear diameter, number of rows/ear, number of grains/row, ear weight, grain weight/ear, 100-grain weight and grain yield /fed as compared with three-way cross hybrid in the two growing seasons. Kandil (2013) found that hybrid S.C.-10 gave the maximum 1000-kernel weight with $357 \mathrm{~kg} \mathrm{~N} / \mathrm{ha}$, while the minimum weight of 1000 -kernel was obtained by S.C. -129 with nitrogen level $214 \mathrm{~kg} / \mathrm{ha}$.

In Egypt, a tremendous mass of filter mud is annually produced as a by-product obtained from the clarification of cane juice in the sugar industries Arafat et al. (1992) tried to examine the effect of filter mud cake on soil characteristics cultivated with maize. Data revealed that the application of filter mud cake at rates of 2 and $4 \%$ induced significant increase of dry matter yield. Also, it has been observed that filter mud cake raised the 
concentrations of NPK as well as the uptake by maize plants. Tejada and Gonzalez, (2004) and Marwa (2007) found that the organic matter in soil play an important role through building up soil aggregates and enhancing proper soil physical and chemical properties. The application of organic matter to examined sand soil improved its physical as well as chemical and fertility properties, characteristic the positive effect of compost application. Azam Shah et al. (2010) revealed that integrated application of organic N sources (farmyard manure, poultry manure and filter cake) and mineral $\mathrm{N}$ source (urea) resulted an upward trend in the yield of maize crop. Maximum biomass, $(9554 \mathrm{~kg} / \mathrm{ha})$ and stover yield $(8136 \mathrm{~kg} / \mathrm{ha})$ of maize were obtained from those treatments where $100 \%$ (FYM) was used. Maximum grain yield $(1838 \mathrm{~kg} / \mathrm{ha})$ was recorded from treatment where $25 \%$ farmyard manure (FYM) and $75 \%$ mineral nitrogen source (urea) were used.

\section{MATERIALS AND METHODS}

Two field experiments were conducted at Sohag Governorate, Egypt, during the summer of 2011 and 2012 seasons. The aim of this research was to study the response of some maize hybrids to different nitrogen fertilization levels and filter mud cake. A split-split plot design with three replications were used. Two Maize Hybrids $\left(\mathrm{H}_{1}\right.$ - Single cross Watania- 4 and $\mathrm{H}_{2}$ - Three way cross-310) were allocated in the main plots. Nitrogen fertilization levels $\left(\mathrm{N}_{1}\right.$ $80, \mathrm{~N}_{2}-100$ and $\mathrm{N}_{3} 120 \mathrm{~kg} \mathrm{~N} / \mathrm{fed}$ ) were distributed in the sub plots. While, organic fertilizer (filter mud cake $\mathrm{B}_{1}$ - Control without addition, $\mathrm{B}_{2}$ - one ton/fed, $\mathrm{B}_{3^{-}}-1.5$ ton/fed and $\mathrm{B}_{4^{-}} 2$ ton/fed) were randomly distributed in the sub-sub plots. The experimental unit area was $10.5 \mathrm{~m}^{2}$ (1/400 feddan). Nitrogen fertilizer was applied on tow doses. The $1^{\text {st }}$ dose of nitrogen fertilization was added before the first irrigation, the $2^{\text {nd }}$ dose of nitrogen fertilization was added before the second irrigation in the form of Urea $(46.5 \% \mathrm{~N})[\mathrm{CO}$ $(\mathrm{NH} 2) 2]$. Filter mud cake contents, total $\mathrm{N}(2.05 \%)$, total $\mathrm{P}(1.49 \%)$ and total $\mathrm{K}(0.95 \%)$ and Macro elements (mg/kg) i.e., Fe, 7540, Mn 281, Zn 102 and Cu173, organic mater $31.60 \%$, organic C\% 18.33, PH (1:5) Susp 7.61 EC $(\mathrm{dsm}-1)(1: 5) 1.050 \mathrm{C} / \mathrm{N}$ Ratio 9:1. Chemical and physical properties of the experimental soil are presented in Table (1).

At harvest time on the first week of October of two seasons, the inner tow rows of each plot were harvested and the ears were collected, counted and weighted, a sample of 5 ears from each plot was taken at random and the following data were recorded: 1- Ear length $(\mathrm{cm})$. 2- Ear diameter $(\mathrm{cm})$. 3Number of rows/ear. 4- Number of kernel/ear. 5- Ear weight (gm). 6- Grains weight/ear (gm). 7- 100 - grain weight (gm), adjusted to $15.5 \%$ moisture. 8Grain yield (ardab/feddan). It was determined by the weight of grains per kilograms adjusted to $15.5 \%$ moisture content of each plot, then converted to ardab/feddan (one ardab $=140 \mathrm{~kg}$ ) The data were statistically analyzed according to Gomez and Gomez (1984), using the computer "MSTAT-C" statistically analysis package by Freed et al. (1989). The least significant differences (LSD) treatment at probability level at 0.05 was manually calculated to compare the differences among means 
Table 1: Physical and chemical properties of the upper $40 \mathrm{~cm}$ of the experimental soil sites

\begin{tabular}{|c|c|c|c|}
\hline \multicolumn{2}{|c|}{ Season } & 2011 & 2012 \\
\hline \multirow{3}{*}{$\begin{array}{l}\text { Physical } \\
\text { analysis }\end{array}$} & Sand \% & 43.60 & 42.00 \\
\hline & Silt \% & 27.20 & 24.71 \\
\hline & Clay \% & 29.20 & 33.29 \\
\hline \multicolumn{2}{|l|}{ Soil texture } & Clay Loam & Clay Loam \\
\hline \multirow{14}{*}{$\begin{array}{l}\text { Chemical } \\
\text { analysis }\end{array}$} & N Available (ppm) & 0.22 & 0.20 \\
\hline & Total - P $(\%)$ & 0.04 & 0.05 \\
\hline & Total $-\mathrm{K}(\%)$ & 0.09 & 0.07 \\
\hline & $\mathrm{CaCo3} \%$ & 0.85 & $1.38 \%$ \\
\hline & Co3 Meq / 100g & Absent & Absent \\
\hline & HCo3 Meq / 100g & 0.57 & 0.22 \\
\hline & $\mathrm{Cl}-\mathrm{Meq} / 100 \mathrm{~g}$ & 0.77 & 0.24 \\
\hline & So4 $=$ Meq $/ 100 \mathrm{~g}$ & 0.60 & 0.60 \\
\hline & $\mathrm{Ca}++\mathrm{Meg} / 100 \mathrm{~g}$ & 0.87 & 0.50 \\
\hline & $\mathrm{Mg}++\mathrm{Meq} / 100 \mathrm{~g}$ & 0.45 & 0.30 \\
\hline & $\mathrm{Na}+\mathrm{Meq} / 100 \mathrm{~g}$ & 0.25 & 0.16 \\
\hline & $\mathrm{K}+$ Meq $/ 100 \mathrm{~g}$ & 0.27 & 0.10 \\
\hline & $\mathrm{EC}(\mathrm{ds} / \mathrm{m})(1: 5)$ & 1.021 & 1.010 \\
\hline & $\mathrm{PH}$ & 7.85 & 7.25 \\
\hline & hic mater & 1.09 & $0.87 \%$ \\
\hline
\end{tabular}

Table 2: Chemical composition of filter mud cake used in the experiments.

\begin{tabular}{|c|c|c|}
\hline \multirow{3}{*}{ Macro elements (\%) } & Total -N (\%) & 2.05 \\
\cline { 2 - 3 } & Total - P (\%) & 1.49 \\
\cline { 2 - 3 } & Total - K (\%) & 0.95 \\
\hline \multirow{3}{*}{$\begin{array}{c}\text { Macro elements } \\
\text { (mg/kg) }\end{array}$} & $\mathrm{Fe}$ & 7540 \\
\cline { 2 - 3 } & $\mathrm{Mn}$ & 281 \\
\cline { 2 - 3 } & $\mathrm{Zn}$ & 102 \\
\cline { 2 - 3 } & $\mathrm{Cu}$ & 173 \\
\hline \multirow{5}{*}{} & Organic matter \% & 31.60 \\
\cline { 2 - 3 } & Organic - C \% & 18.33 \\
\cline { 2 - 3 } & $\mathrm{PH}(1: 5)$ Susp & 7.61 \\
\cline { 2 - 3 } & $\mathrm{EC}$ (dsm-1)(1:5) & 1.050 \\
\cline { 2 - 3 } & C/N Ratio & $9: 1$ \\
\hline
\end{tabular}

\section{RESULTS AND DISCUSSION}

\section{Ear length, ear diameter and number of rows/ear:}

The results in Tables 3 and 4 clearly showed that maize hybrids were significant differences in ear length, ear diameter and number of rows/ear in both seasons. Single cross Watania-4 hybrid produced the highest ear length, ear diameter and number of rows/ear which were 23.24, 4.04 and $12.96 \mathrm{~cm}$ in 2011 and 21.84, 4.12 and 12.84 in 2012 seasons, respectively. These results could be attributed to the genetic differences among the two studied hybrids. Similar results were obtained by Ahmed, Manar (2009). 
J. Plant Production, Mansoura Univ., Vol. 5 (8), August, 2014 
IBrahim,M.M.

$1 \leqslant 97$ 
The results in Tables 3 and 4 showed that ear length, ear diameter and number of rows/ear were affected by application of nitrogen fertilizer levels, the highest values $(23.34,4.24$ and13.30 in 2011 season and 21.95, 4.27 and 13.28 rows/ear) being at $120 \mathrm{~kg} \mathrm{~N} / \mathrm{fed}$ in 2012 seasons, respectively, where the lowest value of $(21.24,3.50$ and 11.80 in 2011 season and 20.15, 3.61 and 11.76 rows/ear in 2012 season, respectively, were recorded at level $80 \mathrm{~kg} \mathrm{~N} / \mathrm{fed}$ in the two seasons. This is to be expected since nitrogen fertilizer may activate vegetative growth and consequently increased plant and ear height. Therefore, the amount of metabolites may be increased in such case which contributed to a large extent in increasing yield components of corn. These results are in harmony with those reported by Attia et al. (2008), Ahmed, Manar (2009), Mansour and Abd El Maksoud (2009) and Maryam, Jasemi et al. (2013).

Results given in Tables 3 and 4 clearly showed that ear length, ear diameter and number of rows/ear were statistically affected by filter mud cake applications. These effects were true in the $1^{\text {st }}$ and $2^{\text {nd }}$ seasons. Regardless the significant effect, the available results revealed that the most effective dose of filter mud cake on ear length, ear diameter and number of rows/ear were between control or 1.0 and 2 ton/fed. The positive effect of filter mud cake on number of rows/ear is mainly due to important role of filter mud cake as the most important element in building up plant organs.

The effect of the maize hybrids $x$ nitrogen fertilizer levels interaction on ear length was insignificantly in both seasons, while, ear diameter was affected in the second season only. Moreover, number of rows/ear were significantly affected in both seasons.

The effect of the maize hybrids $x$ fliter mud cake interaction on ear diameter/cm was significantly in both seasons, while, ear length affected in the second season and number of rows/ear affected in thee first season only. The highest ear diameter/cm was 4.57 and $4.63 \mathrm{~cm}$ which recorded by $\mathrm{H}_{1}$ and 2.0 ton/fed. fliter mud cake in the $1^{\text {st }}$ season and $2^{\text {nd }}$ seasons, respectively.

The effect of nitrogen fertilizer levels $x$ fliter mud cake on ear diameter was significantly in both seasons. Ear length was affected in the second season only. Number of rows/ear was significantly affected in the interaction among nitrogen fertilizer levels $x$ fliter mud cake in both seasons. The highest number of rows/ear were 14.37 and 14.43 which recorded by $120 \mathrm{~kg} \mathrm{~N} / \mathrm{fed}$ and 2.0 ton/fed filter mud cake in the $1^{\text {st }}$ and $2^{\text {nd }}$ seasons, respectively.

Ear diameter was significantly affected by the interactions among the three studied factors in both seasons, while, ear length and number of rows/ear significantly affected only in the first season. Planting $\mathrm{H}_{1}$ and fertilizing with $120 \mathrm{~kg} \mathrm{~N} / \mathrm{fed}$ and 2.0 ton filter made cake gave the highest ear length, ear diameter and number of rows/ear.

\section{Ear weight (gm), number of kernel/ear and grains weight/ear (gm):}

The results in Tables 5 and 6 showed that maize hybrids were significant differences in ear weight gm in both seasons, while, number of kernel/ear and grains weight/ear gm were significant in the first season only. Single cross Watania-4 hybrid produced the highest ear weight/gm, number 
of kernel/ear and grains weight/ear gm $(213.21 \mathrm{gm}, 577.59$ and $169.20 \mathrm{gm}$ in $1^{\text {st }}$ season and $259.34 \mathrm{gm}, 565.22$ and $196.61 \mathrm{gm}$ ) in the $2^{\text {nd }}$ season, respectively. These results could be attributed to the genetic differences among two hybrids studied. Similar results were obtained by Ahmed, Manar (2009). The results in Tables 5 and 6 showed that ear weight/gm, number of kernel/ear and grains weight/ear gm were affected by nitrogen fertilizer levels in both seasons, the highest values $215.97 \mathrm{gm}, 616.28$ and $172.94 \mathrm{gm}$ in $1^{\text {st }}$ season and $256.99 \mathrm{gm}, 606.71$ and $197.88 \mathrm{gm}$ being at $120 \mathrm{~kg} \mathrm{~N} / \mathrm{fed}$ in the $2^{\text {nd }}$ season, respectively. Where, the lowest values which were $201.56 \mathrm{gm}$, 520.84 and $155.81 \mathrm{gm}$ in the $1^{\text {st }}$ season and $247.51 \mathrm{gm}, 513.50$ and 197.88 $\mathrm{gm}$ in the $2^{\text {nd }}$ season, respectively were recorded at nitrogen fertilizer level of $80 \mathrm{~kg} \mathrm{~N} / \mathrm{fed}$. in the tow seasons. This is to be expected since nitrogen fertilizer may activate vegetative growth. Therefore the amount of metabolites may be increased in such case which contributed to a large extent in increasing yield components of corn. These results are in harmony with those reported by Attia et al. (2008), Ahmed, Manar (2009), Mansour and Abd El Maksoud (2009) and Maryam, Jasemi et al. (2013).

Results given in Tables 5 and 6 clearly showed that was statistically affected by filter mud cake applications. These effects were true in the $1^{\text {st }}$ and $2^{\text {nd }}$ seasons. Regardless the significant effect, the available results revealed that the most effective dose of filter mud cake on ear weight/gm, number of kernel/ear and grains weight/ear gm were between control or 1.0 and 2 ton/fed. The positive effect of filter mud cake ear weight gm, number of kernel/ear and grains weight/ear gm is mainly due to important role of filter mud cake as the most important element in building up plant organs.

The effect of the maize hybrids $x$ nitrogen fertilizer levels interaction on ear weight gm and number of kernel/ear were significantly in both seasons.

The effect of the maize hybrids $x$ filter mud cake interaction on ear weight/gm, number of kernel/ear and grains weight/ear were significantly in both seasons. The effect of nitrogen fertilizer levels $x$ filter mud cake interaction on number of kernel/ear was affected in both seasons, while, ear weight/gm and grains weight gm significantly affected in the $1^{\text {st }}$ season only.

Ear weight/gm was significantly affected by the interactions among the three studied factors in the first season only, while, number of kernel/ear and grains weight/ear gm significantly affected in the second season only. Planting $\mathrm{H}_{1}$ and fertilized with $120 \mathrm{~kg} \mathrm{~N} / \mathrm{fed}$ and application of 2.0 ton filter made cake gave the highest ear weight/gm.

3- 100-grain weight (gm) and grain yield ardab/feddan.

Results in Tables 7 and 8 clearly showed that the two maize hybrids differed significantly for 100 - grain weight/gm and grain yield ardab/fed in both seasons. Single cross Watania- $4 \mathrm{H}_{1}$ surpassed three ways cross- $310 \mathrm{H}_{2}$ in 100- grain weight/gm by 2.31 and $2.02 \mathrm{gm}$ and grain yield by 2.39 and 2.49 ardab/fed in 2011 and 2012 seasons, respectively. These results could be attributed to the genetic differences among two studied hybrids. Similar results were obtained by Abd El-Aty (2007), Ahmed, Manar (2009), Ahmed, Howida (2011), Moharam, Zainab (2011) and Kandil (2013). 
J. Plant Production, Mansoura Univ., Vol. 5 (8), August, 2014 $-5-6$ 
Results presented in Tables 7 and 8 revealed that increasing nitrogen fertilizer rates significantly increased 100-grain weight $(\mathrm{gm})$ and grain yield ardab/fed in both seasons. Highest 100-grain weight/gm (36.06 and $41.70 \mathrm{gm})$ and highest grain yield (24.25 and $27.74 \mathrm{ardab} / \mathrm{fed})$ were obtained at $120 \mathrm{~kg} \mathrm{~N} / \mathrm{fed}$ in both seasons, respectively. Whereas the lowest one (32.71 and $38.29 \mathrm{gm}$ and 21.34 and $24.24 \mathrm{ardab} / \mathrm{fed}$ ) were recorded when applied $80 \mathrm{~kg} \mathrm{~N} / \mathrm{fed}$ in the two season, respectively. These results may be due to the increase of photosynthetic surface, which in turn resulted in an increase in metabolic processes and building more grain yield. Furthermore, the effect of nitrogen in increasing the vegetative growth and its components consequently increased the 100- grain weight and grain yield. These results are confirmed by those reported by Attia et al. (2008), Ahmed, Manar (2009), Mansour and Abd El Maksoud (2009), Maryam Jasemi et al. (2013).

Results in Tables 7 and 8 clearly indicated that application of filter mud cake (FMC) as organic fertilizer has a significant influence on 100-grain weight/gm and grain yield (ardab/feddan) in both seasons. In general, 100grain weight/gm and grain yield ardab/feddan gradually increased by increasing FMC rate. The increase of yield supplied with 1.0, 1.5 and 2.0 ton FMC/fed over the control were 2.54, 4.37 and $6.15 \mathrm{gm}$ and 2.19, 3.53 and $5.09 \mathrm{ardab} / \mathrm{fed}$, respectively, in the first season, while in the second season these values were 2.54, 4.18 and $5.66 \mathrm{gm}$ and 2.01, 3.42 and $4.79 \mathrm{ardab} / \mathrm{fed}$, respectively. The increase in 100-grain weight/gm and grain yield (ardab/feddan) as result of FMC application may be due to the increase of dry matter yield. Also, it has been observed that filter mud cake raised the concentrations of NPK as well as the uptake by maize plants (Arafat et al. 1992). This is due to stimulation effect on plant growth of treated plants and increases the ability of such plant to form more metabolites required for building more plant organs. These results are in line with those obtained by Azam Shah et al. (2010) and Ossom and Dlamini (2012).

The effect of the maize hybrids $x$ nitrogen fertilizer levels interaction on 100grain weight/gm and grain yield ardab/fed were significantly in both seasons. Highest weight of 100-grain and grain yield ardab/fed were 37.49 and $42.67 \mathrm{gm}$ and 25.09 and $28.77 \mathrm{ardab} / \mathrm{fed}$ which recorded by $\mathrm{H}_{1}$ with using $120 \mathrm{~kg} \mathrm{~N} / \mathrm{fed}$. in the $1^{\text {st }}$ and $2^{\text {nd }}$ seasons, respectively. The effect of the maize hybrids $\mathrm{x}$ fliter mud cake interaction on 100-grain weight/gm was significantly in both seasons, while, grain yield affected in the first season only. The highest 100-grain weight/gm was $38.64 \mathrm{gm}$ and $43.48 \mathrm{gm}$ which recorded by $\mathrm{H}_{1}$ which fertilized with 2.0 ton/fed. fliter mud cake in the $1^{\text {st }}$ and $2^{\text {nd }}$ seasons, respectively.

The effect of nitrogen fertilizer levels $x$ filter mud cake interaction on 100grain weight/gm was significantly in both seasons, while, grain yield ardab/fed affected in the second season only. Highest weight of 100-grain were 39.33 and 43.81 which recorded by fertilizing with $120 \mathrm{~kg} \mathrm{~N} / \mathrm{fed}$ and a rate of 2.0 ton/fed, while, the highest grain yield ardab/fed. were $29.88 \mathrm{ardab} / \mathrm{fed}$ which recorded by application of $120 \mathrm{~kg}$ $\mathrm{N} / \mathrm{fed}$ and FMC at a rate of 2.0 ton/fed in the second season only. Grain yield ardab/fed was significantly affected by the interactions among the three studied factors in the second season only, planting $H_{1}$ and application of $120 \mathrm{~kg} \mathrm{~N} / \mathrm{fed}$ and FMC at a rate of 2.0 ton filter made cake gave the highest grain yield ardab/fed which were $30.95 \mathrm{ardab} / \mathrm{fed}$ in the second season. 
J. Plant Production, Mansoura Univ., Vol. 5 (8), August, 2014

7-8

1501 


\section{REFERENCES}

Abd El-Aty, M.S.M. (2007). Diallel analysis of some quantitative traits in seven white hybrid lines of maize under three nitrogen levels. J. Agric. Res. Kafer El-Sheikh Univ., 33(23: 551-575.

Ahmed, A.G. and B.B.,Mekki (2005). Yield and yield components of two maize hybrids as influenced by water deficit during different growth stages. Egypt. J. Appl. Sci., 20(2): 64-79.

Ahmed, Howida E.A. (2011). Effect of spatial distribution of plant under different watering regimes on the yield and its components of corn (Zea mayes L.). M.Sc. Thesis, Agron. Dept. Fac. Agric., Assiut Univ. Egypt.

Ahmed, Manar A.M. (2009). Yield and quality of maize in response to biofertilizer application. M. Sc, Thesis, Agron. Dept. Fac. Agric., Assiut Univ. Egypt

Arafat, S.M.; M. Abou Seeda; M.A. Sherif and M.A. Rasheed. (1992). Beneficial effect of filter mud on agro-chemical characteristics of sandy soil. Zagazig J. Agric. Res., 19 (4B): 1907-1915.

Attia, A.N.E.; S.A. El-Moursy; E.M. Said and A.A.S. El-Azab (2008). Response of maize growth and yield to sowing methods, mechanical weed control and nitrogen fertilizer levels. J. Agric. Sci. Mansoura Univ., 33 (11): 7771-7782.

Azam S.; M. Shafi; J. Bakht; W. Mohammad; M. Shah and Raziuddin (2010). Effect of integrated use of nitrogen on yield and $N$ uptake of maize crop. Pak. J. Bot., 42(5): 3633-3638.

Bamuaafa, M.S.S. (2012). Effect of irrigation and nitrogen fertilization on yield and quality of corn. Ph.D. Thesis, Agron. Dep. Fac., Agric., Assiut Univ., Egypt.

Freed, R.S.P.; S.P. Eisensmith; S. Goetez; D. Recosky; V.W. Smail; and P. wolberg (1989). User's Guide MSTAT-C Software program for the design management and analysis of agronomic research experiments. Michingan State University, U.S.A.

Gomez, K.A. and A.A. Gomez (1984). Statistical Procedures for Agricultural Research. John Willey and Sons. Inc. New York.

Gouda, A.Sh.A. and A.Y.A. El-Banna (1995). Response of some maize varieties to nitrogen fertilization under sandy soil conditions. Egypt.J. Appl. Sci., 10(3):587-594.

Ibrahim, S.A. and Kandil Hala (2007). Growth yield and grain chemical comstituents of corn (Zea mays L) as affected by nitrogen and phosphors fertilization under different irrigation intervals. J. Appl. Sciences. Res., 3 (10): 1112-1120.

Kandil, E.E.E. (2013). Response of some maize hybrids (Zea mays L.) to different levels of nitrogenous fertilization. J. Appl. Sci. Res., 9(3): 1902-1908.

Mansour, A.A. and M.F. Abd-El-Maksoud (2009). Response of some maize hybride to nitrogen fertilizer levels under cultivated sandy soils. J. Agric. Sci. Mansoura Univ., 34 (4):3335-3347.

$$
10 . r
$$


Marwa, A.A. (2007). Evaluation of some amendments in new reclaimed soils. MSc. Thesis, Fac. of agric Zagazig Univ. Egypt.

Maryam Jasemi; Fereshteh Darabi and Rahim Naseri (2013). Effect of planting date and nitrogen fertilizer application on grain yield and yield components in maize (SC 704). American-Eurasian J. Agric. \& Environ. Sci., 13 (7): 914-919.

Moharram, Zainab A.M. (2011). Physiological response of corn hybrids to some cultural practices. M. Sc. Thesis, Agron. Dep., Fac. Agric., Assiut Univ., Egypt.

Ossom, E.M. and F.T. Dlamini (2012). Effects of filter cake on soil mineral nutrients and maize (Zea mays L.) agronomy. "Tropical Agriculture, 89, (3): 141-150.

Salem, M.A. (2000). Response of maize (Zea mays L) growth and yield to chemical and biofertilization. Zagaizg, J. Agric. Res., (4): 845-858.

Shafshak, S.E.; G.Y. Hammam; M. Samia Amer and A.E. Fatma Nofal (1994). Differential growth and yield response of some maize genotype to nitrogen fertilization. Annals of Agric. Sci., Moshtohor, 32 (3): 12651278.

Tejada, M. and J.L. Gonzalez (2004). Effects of application of a byproduct of the two-step olive oil mill process on maize yield. Agron. J., 96: 692699.

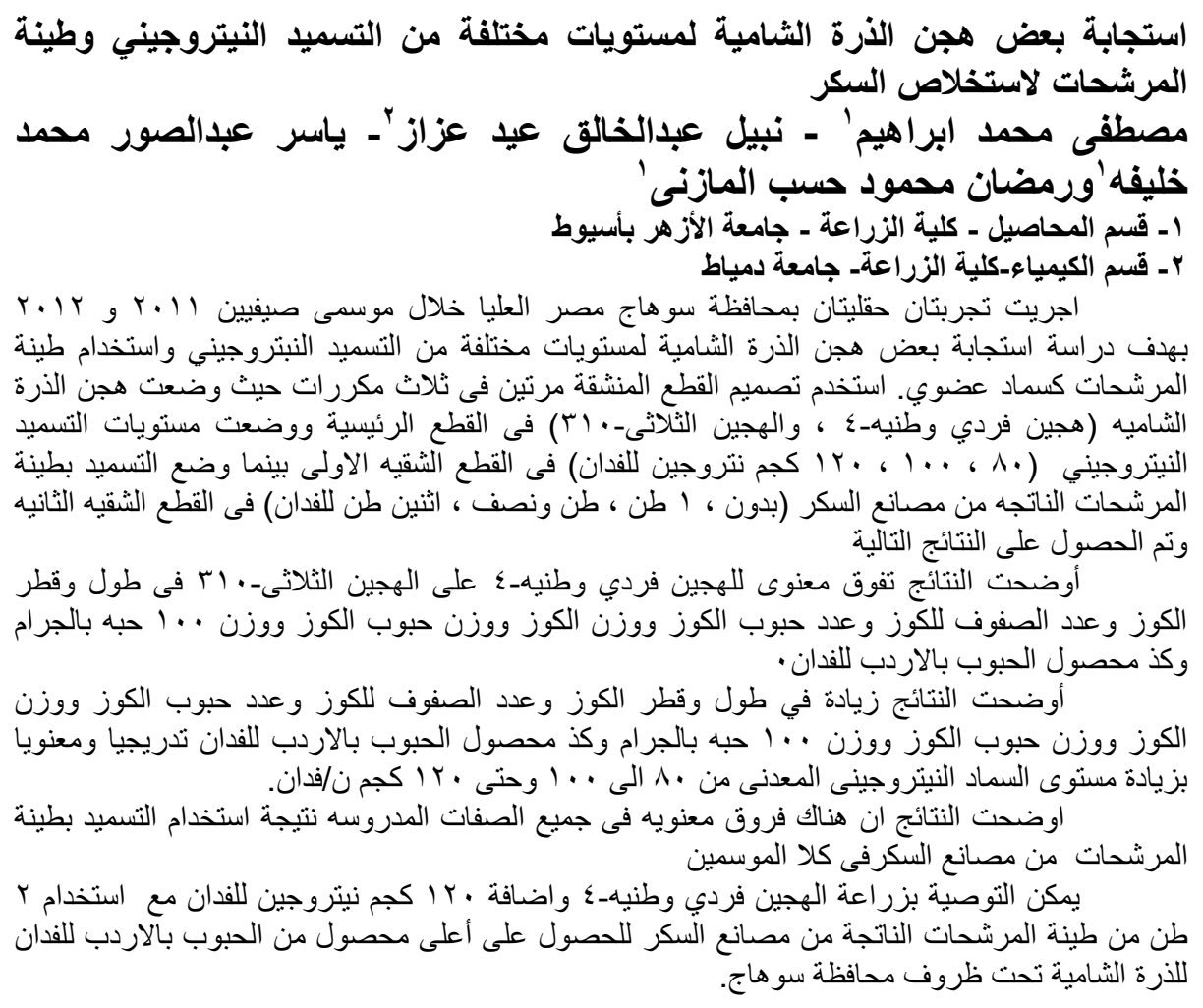



Table 3: Means of Ear length, ear diameter $(\mathrm{cm})$ and number of rows/ear of maize hybrids as affected by nitrogen fertilizer levels and filter mud cake and their interactions in 2011 season

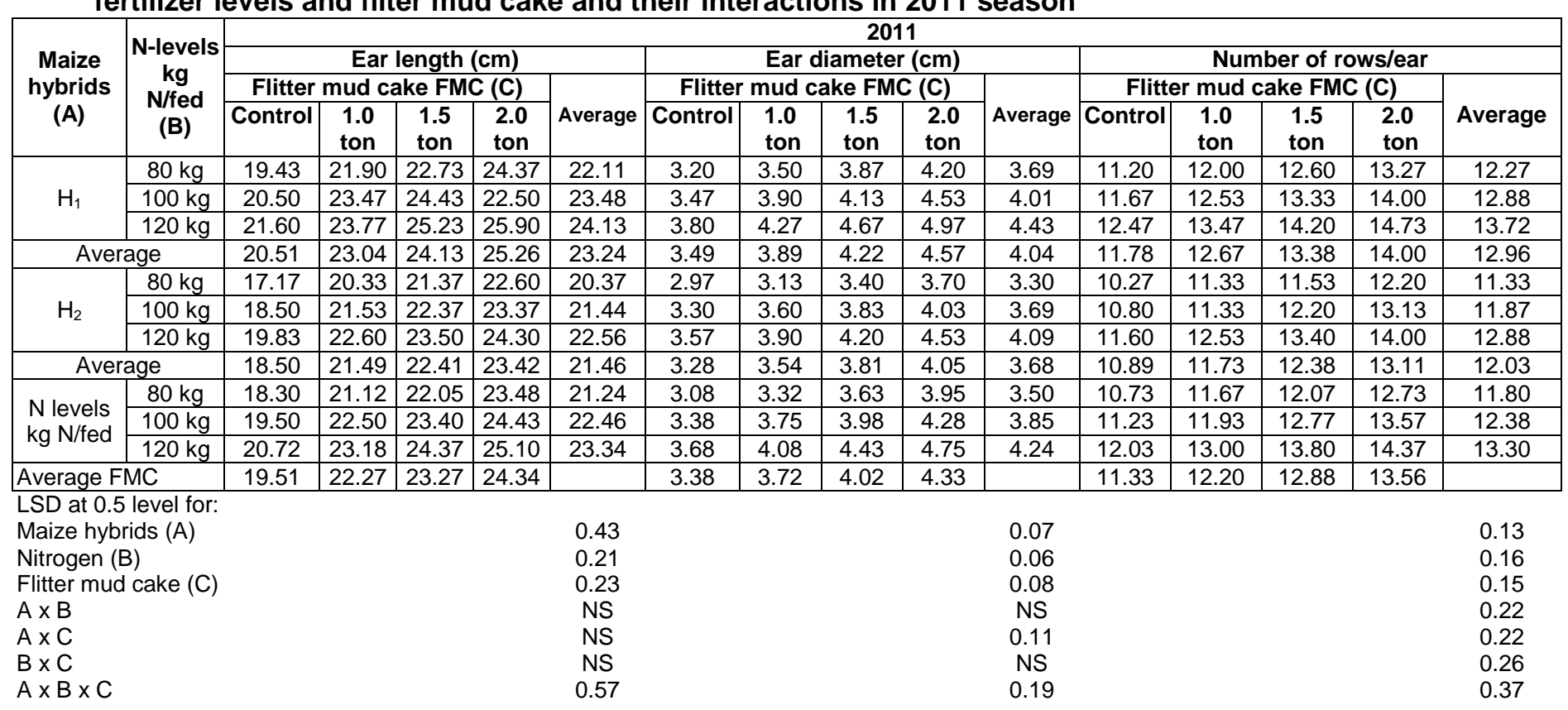


Table 4: Means of Ear length, ear diameter $(\mathrm{cm})$ and number of rows/ear of maize hybrids as affected by nitrogen fertilizer levels and filter mud cake and their interactions in 2012 season

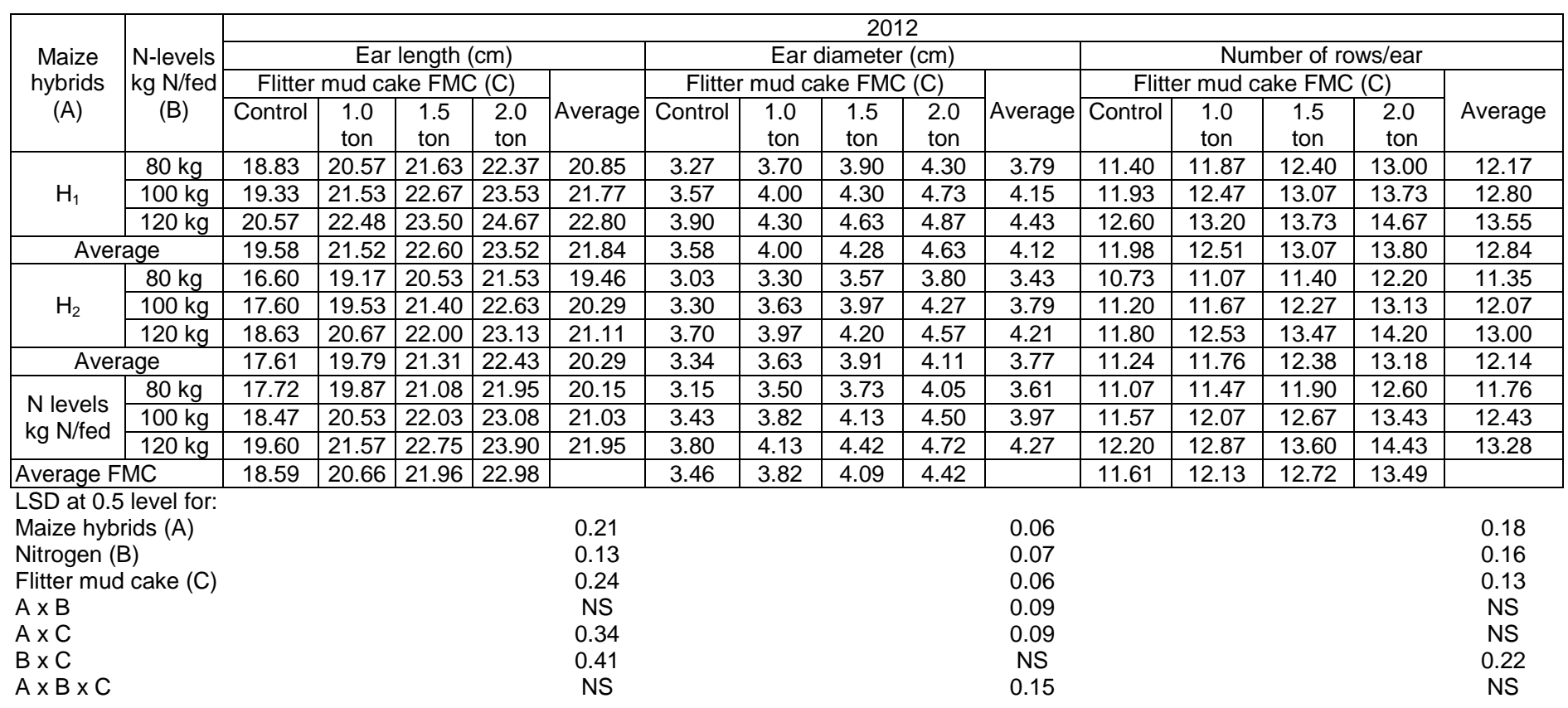


J. Plant Production, Mansoura Univ., Vol. 5 (8), August, 2014 
Table 5: Means of Ear weight (gm), number of kernel/ear and grains weight/ear (gm) of maize hybrids as affected by nitrogen fertilizer levels and filter mud cake and their interactions in 2011 season

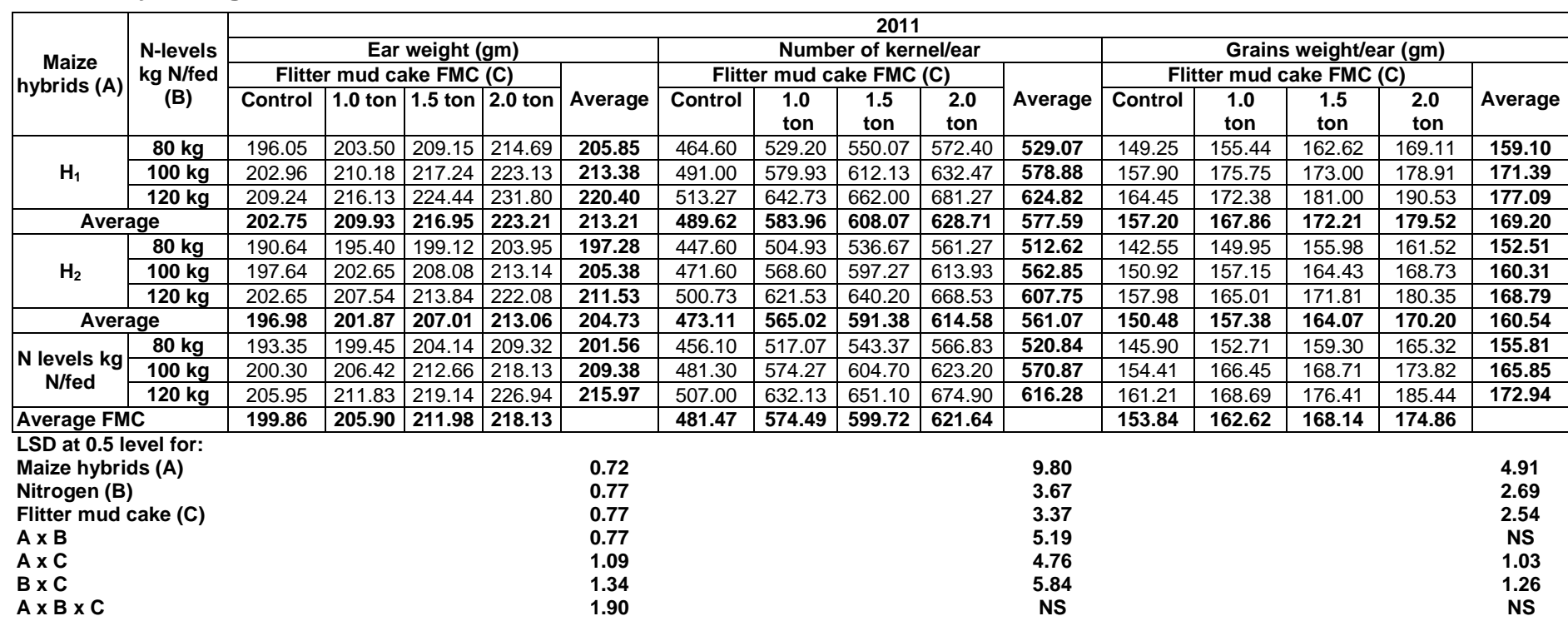


Table 6: Means of Ear weight (gm), number of kernel/ear and grains weight/ear (gm) of maize hybrids as affected by nitrogen fertilizer levels and filter mud cake and their interactions in 2012 season

\begin{tabular}{|c|c|c|c|c|c|c|c|c|c|c|c|c|c|c|c|c|}
\hline \multirow{4}{*}{$\begin{array}{l}\text { Maize hybrids } \\
\text { (A) }\end{array}$} & \multirow{4}{*}{$\begin{array}{l}\text { N-levels kg } \\
\text { N/fed (B) }\end{array}$} & \multirow{2}{*}{\multicolumn{10}{|c|}{ Ear weight $(\mathrm{gm})$}} & & & & & \\
\hline & & \multicolumn{5}{|c|}{$\begin{array}{ll}\text { Ear weight (gm) } \\
\end{array}$} & & & & & & \multicolumn{5}{|c|}{ Grains weight/ear (gm) } \\
\hline & & \multicolumn{4}{|c|}{ Flitter mud cake FMC (C) } & \multirow[b]{2}{*}{ Average } & \multicolumn{4}{|c|}{ Flitter mud cake FMC (C) } & \multirow[b]{2}{*}{ Average } & \multicolumn{4}{|c|}{ Flitter mud cake FMC (C) } & \multirow[b]{2}{*}{ Average } \\
\hline & & Control & 1.0 ton & 1.5 ton & 2.0 ton & & Control & $\begin{array}{l}1.0 \\
\text { ton }\end{array}$ & $\begin{array}{l}1.5 \\
\text { ton }\end{array}$ & $\begin{array}{l}2.0 \\
\text { ton }\end{array}$ & & Control & $\begin{array}{l}1.0 \\
\text { ton }\end{array}$ & $\begin{array}{l}1.5 \\
\text { ton }\end{array}$ & $\begin{array}{l}2.0 \\
\text { ton }\end{array}$ & \\
\hline \multirow{3}{*}{$\mathrm{H}_{1}$} & $80 \mathrm{~kg}$ & 245.61 & 251.16 & 256.04 & 260.55 & 253.34 & 454.67 & 517.00 & 540.07 & 557.40 & 517.28 & 182.16 & 187.90 & $\frac{101}{192.55}$ & $\frac{1001}{195.33}$ & 189.48 \\
\hline & & 251.75 & 257.18 & 263.40 & 267.54 & & 479.00 & 567.00 & 607.13 & 624.13 & & 188.95 & & 199.33 & & \\
\hline & $120 \mathrm{~kg}$ & 254 & 263.11 & 268.28 & 273. & 26 & 50 & 635.40 & 621.67 & 674 & & 197.38 & 201 & 206 & 211.56 & \\
\hline \multicolumn{2}{|c|}{ Average } & 250 & 257.15 & & 267.19 & & & 573.13 & 589.62 & & & & & & & \\
\hline \multirow{3}{*}{$\mathrm{H}_{2}$} & & 233.95 & 239.24 & 244.85 & 248.70 & 241 & 448.20 & 506.40 & 534.20 & 550.07 & 509. & 169.85 & 208.45 & 182.48 & & 180.35 \\
\hline & $100 \mathrm{~kg}$ & 237.54 & 241.16 & 247.78 & 251.10 & 244. & 468.27 & 570.60 & 593.93 & 610.60 & 560.85 & 176.86 & 183.63 & 190.27 & 196.10 & 186.72 \\
\hline & 120 & 242.90 & 246.65 & 250.36 & 257.08 & 249 & 496.73 & 618.20 & 637.40 & 665.13 & 608.60 & 184.51 & 189.77 & 194.21 & 198.07 & $\frac{100.1 / 2}{191.64}$ \\
\hline \multicolumn{2}{|c|}{ Average } & 238.13 & 242.35 & 247.66 & 252.30 & 245 & 471.07 & 565.07 & 588.51 & 604.37 & 558 & 177.07 & 193.95 & 188.99 & 194.26 & 188.57 \\
\hline \multirow{4}{*}{$\begin{array}{c}\begin{array}{c}\text { N levels kg } \\
\text { N/fed }\end{array} \\
\text { Average FMC }\end{array}$} & $80 \mathrm{~kg}$ & 239.78 & 245.20 & 250.44 & 254.62 & & 451.43 & 511.70 & 537.13 & 553.73 & & 176.00 & 198.18 & 187.52 & & 188.42 \\
\hline & & 244.65 & 249.17 & 255.59 & 259.32 & & & 568.80 & 600.53 & 617.37 & & & & & & \\
\hline & $120 \mathrm{~kg}$ & 248.46 & 254.88 & 259.32 & 265.28 & 256.99 & 500.67 & 626.80 & 629.53 & 669.83 & 606.71 & 190.95 & 195.59 & 200.15 & & 197.88 \\
\hline & & 244.30 & 249.75 & 255.12 & 259.74 & & 475.60 & 569.10 & 589.07 & 613.64 & & 183.28 & $\begin{array}{r}194.09 \\
\end{array}$ & 194.16 & $\begin{array}{l}198.82 \\
\end{array}$ & \\
\hline \multirow{2}{*}{\multicolumn{2}{|c|}{$\begin{array}{l}\text { LSD at } 0.5 \text { level for: } \\
\text { Maize hybrids ( } A \text { ) } \\
\text { Nitrogen (B) }\end{array}$}} & & & & & & & & & & & & & & & \\
\hline & & & & & & 0.9 & & & & & NS & & & & & $\begin{array}{l}\text { NS } \\
\text { NS }\end{array}$ \\
\hline \multirow{2}{*}{\multicolumn{2}{|c|}{$\begin{array}{l}\text { Nitrogen (B) } \\
\text { Flitter mud cake (C) }\end{array}$}} & & & & & & & & & & & & & & & $\begin{array}{l}\text { NS } \\
796\end{array}$ \\
\hline & & & & & & & & & & & & & & & & NS \\
\hline & & & & & 1.3 & & & & & & & & & & $\begin{array}{l}11.26 \\
11.26\end{array}$ \\
\hline & & & & & NS & & & & & 16.28 & & & & & NS \\
\hline & & & & & & & & & & & & & & & & \\
\hline
\end{tabular}


Table 7: Means of 100-grain weight (g) and grain yield ardab/fed of maize hybrids as affected by nitrogen fertilizer levels and organic fertilizer using filter mud cake and their interactions in 2011 season

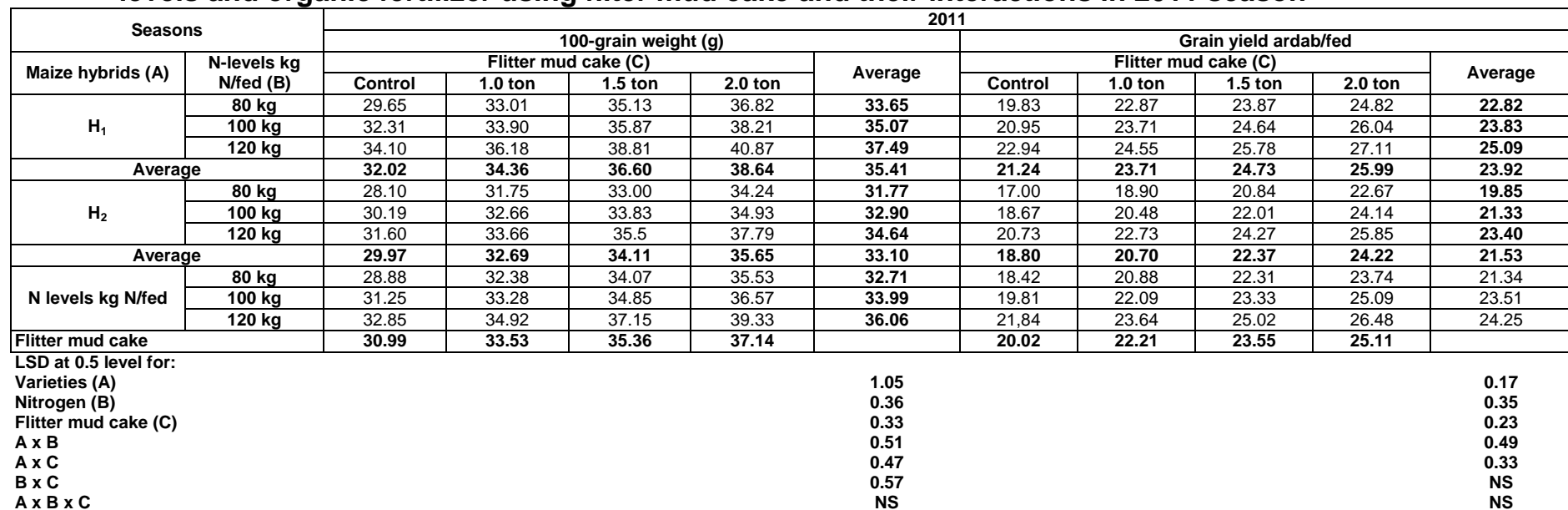

Table 8: Means of 100-grain weight (g) and grain yield ardab/fed of maize hybrids as affected by nitrogen fertilizer levels and organic fertilizer using filter mud cake and their interactions in 2012 season

\begin{tabular}{|c|c|c|c|c|c|c|c|c|c|c|c|}
\hline \multirow{2}{*}{\multicolumn{2}{|c|}{ Seasons }} & \multicolumn{10}{|c|}{2012} \\
\hline & & \multicolumn{5}{|c|}{ 100-grain weight (g) } & \multicolumn{5}{|c|}{ Grain yield ardab/fed } \\
\hline \multirow{2}{*}{ Maize hybrids (A) } & \multirow{2}{*}{$\begin{array}{c}\mathrm{N} \text {-evels kg } \\
\mathrm{N} / \text { fed (B) }\end{array}$} & \multicolumn{4}{|c|}{ Flitter mud cake (C) } & \multirow{2}{*}{ Average } & \multicolumn{4}{|c|}{ Flitter mud cake (C) } & \multirow{2}{*}{ Average } \\
\hline & & Control & 1.0 ton & 1.5 ton & 2.0 ton & & Control & 1.0 ton & 1.5 ton & 2.0 ton & \\
\hline \multirow{3}{*}{$\mathrm{H}_{1}$} & $80 \mathrm{~kg}$ & 35.55 & 38.92 & 40.98 & 43.44 & 39.72 & 23.00 & 25.19 & 26.58 & 28.15 & 25.73 \\
\hline & $100 \mathrm{~kg}$ & 37.70 & 39.39 & 40.65 & 42.31 & 40.01 & 24.39 & 26.36 & 27.64 & 28.92 & 26.83 \\
\hline & $120 \mathrm{~kg}$ & 40.11 & 42.18 & 43.72 & 44.69 & 42.67 & 25.92 & 28.64 & 29.75 & 30.95 & 28.77 \\
\hline \multicolumn{2}{|c|}{ Average } & 37.79 & 40.16 & 41.78 & 43.48 & 40.80 & 24.44 & 26.67 & 27.99 & 29.34 & 27.11 \\
\hline \multirow{3}{*}{$\mathrm{H}_{2}$} & $80 \mathrm{~kg}$ & 33.22 & 36.60 & 38.14 & 39.50 & 36.75 & 20.17 & 22.23 & 23.51 & 25.11 & 22.76 \\
\hline & $100 \mathrm{~kg}$ & 36.09 & 38.06 & 39.59 & 41.25 & 38.75 & 21.98 & 23.88 & 25.04 & 26.65 & 24.39 \\
\hline & $120 \mathrm{~kg}$ & 37.51 & 40.27 & 42.18 & 42.94 & 40.73 & 24.40 & 25.77 & 27.87 & 28.82 & 26.71 \\
\hline \multicolumn{2}{|c|}{ Average } & 35.61 & 38.31 & 39.97 & 41.23 & 38.78 & 22.18 & 23.96 & 25.47 & 26.86 & 24.62 \\
\hline \multirow{3}{*}{$\mathrm{N}$ levels kg N/fed } & $80 \mathrm{~kg}$ & 34.39 & 37.76 & 39.56 & 41.47 & 38.29 & 21.58 & 23.71 & 25.04 & 26.63 & 24.24 \\
\hline & $100 \mathrm{~kg}$ & 36.89 & 38.72 & 40.12 & 41.78 & 39.38 & 23.18 & 25.12 & 26.34 & 27.78 & 25.61 \\
\hline & $120 \mathrm{~kg}$ & 38.81 & 41.22 & 42.95 & 43.81 & 41.70 & 25.16 & 27.12 & 27.78 & 29.88 & 27.74 \\
\hline & 36.70 & 39.24 & 40.88 & 42.36 & & 23.31 & 25.32 & 25.61 & 28.10 & \\
\hline \multicolumn{2}{|c|}{$\begin{array}{l}A \times B \\
A \times C \\
B \times C \\
A \times B \times C\end{array}$} & & & & & $\begin{array}{l}0.21 \\
0.27 \\
0.40 \\
0.39 \\
0.06 \\
0.69 \\
\text { NS }\end{array}$ & & & & & $\begin{array}{c}0.37 \\
0.28 \\
0.27 \\
0.40 \\
\text { NS } \\
0.46 \\
0.65\end{array}$ \\
\hline
\end{tabular}


J. Plant Production, Mansoura Univ., Vol. 5 (8), August, 2014 